\title{
Challenges of achieving Good Environmental Status in the Northeast Atlantic
}

\author{
$\underline{\text { Karen A. Alexander }}^{1}, \underline{\text { Peter Kershaw }}^{2}, \underline{\text { Philip Cooper }}^{3}$, Alison J. Gilbert $^{4}, \underline{\text { Jason M. Hall-Spencer }}^{5}, \underline{\text { Johanna J. Hevmans }}^{1}$, Andreas

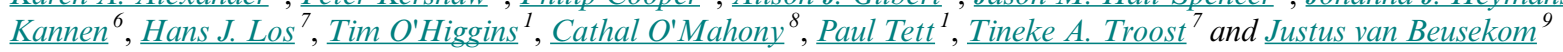

\begin{abstract}
The sustainable exploitation of marine ecosystem services is dependent on achieving and maintaining an adequate ecosystem state to prevent undue deterioration. Within the European Union, the Marine Strategy Framework Directive (MSFD) requires member states to achieve Good Environmental Status (GEnS), specified in terms of 11 descriptors. We analyzed the complexity of social-ecological factors to identify common critical issues that are likely to influence the achievement of GEnS in the Northeast Atlantic (NEA) more broadly, using three case studies. A conceptual model developed using a soft systems approach highlights the complexity of social and ecological phenomena that influence, and are likely to continue to influence, the state of ecosystems in the NEA. The development of the conceptual model raised four issues that complicate the implementation of the MSFD, the majority of which arose in the Pressures and State sections of the model: variability in the system, cumulative effects, ecosystem resilience, and conflicting policy targets. The achievement of GEnS targets for the marine environment requires the recognition and negotiation of trade-offs across a broad policy landscape involving a wide variety of stakeholders in the public and private sectors. Furthermore, potential cumulative effects may introduce uncertainty, particularly in selecting appropriate management measures. There also are endogenous pressures that society cannot control. This uncertainty is even more obvious when variability within the system, e.g., climate change, is accounted for. Also, questions related to the resilience of the affected ecosystem to specific pressures must be raised, despite a lack of current knowledge. Achieving good management and reaching GEnS require multidisciplinary assessments. The soft systems approach provides one mechanism for bringing multidisciplinary information together to look at the problems in a different light.
\end{abstract}

Key Words: ecosystem-based management; Good Environmental Status; Northeast Atlantic; soft systems methodology; trade-offs

\section{INTRODUCTION}

Global seas are facing many threats, particularly those caused by human activity (Millenium Ecosystem Assessment 2005). Environmental change is ultimately driven by humans, and drivers may include, e.g., increasing demand for seafood or for energy. These driving forces lead to pressures such as increasing use of resources, which in turn may lead to ecosystem change (Cooper 2013). For this reason, the Marine Strategy Framework Directive (MSFD; European Parliament and the Council of the European Union 2008) is currently being implemented by European Union (EU) member states, requiring them to apply an ecosystem approach to the management of human activities with an aim to achieve Good Environmental Status (GEnS) of Europe's regional seas by 2020. GEnS is defined as "the environmental status of marine waters where these provide ecologically diverse and dynamic oceans and seas which are clean, healthy and productive" (European Parliament and the Council of the European Union 2008: Chapter 1, Article 3 [5]).

Growing human populations, increased per capita demand for marine ecosystem services, limited space on land, and the pursuit of offshore sources of energy have led to multiple competing drivers and in turn increased pressures across Exclusive Economic Zones in the North East Atlantic (NEA). The NEA has been exploited by society for many centuries, notably for transport, food, and other natural resources; and although this has affected the whole of the Greater North Sea, it is particularly true of the semienclosed shelf seas, i.e., the greater North and Celtic seas. Human pressures have increased considerably over the last century, but concerns about adverse environmental effects are not new. For example, warnings about overfishing in the North Sea were made in the late 19th century (Gulland 1958), with the decline of cod (Gadus morhua) seen in 20 stocks throughout the North Atlantic by the 1990s (Myers et al. 1996).

The increase in the number and extent of maritime activities and the demand for ecosystem services have changed the state of many environmental variables. Examples include the effects of contaminant emissions, e.g., hydrocarbons (e.g. Mendelssohn et al. 2012); changes in biological communities such as those caused by fishing (Thrush and Dayton 2002); introduction of nonindigenous species, e.g., the Rapana whelk (Rapana venosa), potentially through shipping (Kerckhof et al. 2006); and marine litter or microplastics (Cole et al. 2011), which can affect a range of species by causing decreased feeding ability or even death. These multiple competing drivers and pressures create a complexity that makes governance of the marine environment a difficult and complicated task.

The NEA region has well-established environmental governance structures (van Leeuwen et al. 2012). The 1992 OSPAR Convention (http://www.ospar.org), supported by 15 governments including non-EU countries such as Iceland, Norway, and Switzerland, covers dumping and land-based sources of waste and human activities that can affect the NEA. Regional Advisory Councils within Europe prepare and provide advice on fisheries management, with the North Sea Advisory Council (http://www. nsrac.org) being a key council in the NEA area. In addition, the International Council for Exploration of the Sea is an intergovernmental body established in 1902, primarily to

\footnotetext{
${ }^{1}$ Scottish Association for Marine Science, ${ }^{2}$ Centre for Environment, Fisheries \& Aquaculture Science, ${ }^{3}$ School of Management, University of Bath, ${ }^{4}$ Institute for Environmental Studies, VU University of Amsterdam, ${ }^{5}$ School of Marine Science and Engineering, University of Plymouth, ${ }^{6}$ Institute for Coastal Research, Helmholz-Zentrum Geesthacht, ${ }^{7}$ Deltares, ${ }^{8}$ Coastal \& Marine Research Centre, University College Cork, ${ }^{9}$ Institute for Hydrobiology and Fisheries Science, University of Hamburg
} 
encourage research on the living resources of the North Atlantic and act as a data repository. Despite the institutional framework and comprehensive knowledge base, it is apparent that defining and achieving GEnS as characterized by reference to the 11 descriptors prescribed by the MSFD in the NEA will be challenging (Ounanian et al. 2012, Bertram and Rehdanz 2013).

The aim of this study was to analyze the complexity of socialecological factors to identify common critical issues that are likely to influence the achievement of GEnS for the MSFD descriptors in the NEA more broadly. In this paper, we "zoom out" to examine the wider social-ecological system and present a conceptual model developed using a soft systems approach to highlight the complexity of social and ecological phenomena that influence, and are likely to continue to influence, the state of ecosystems in the NEA.

\section{METHODS}

We undertook this research as part of the EU-FP7 funded project KnowSeas (see Mee et al. 2015 in this Special Feature for further information). As part of the aforementioned project, three case studies were undertaken in the NEA region (Fig. 1): an examination of the interaction between trawl fisheries, climate change, and the cold-water coral Lophelia pertusa (Lophelia reefs); an investigation of ecosystem services related to offshore renewable energy development (offshore wind farms); and research into the effects of transboundary nutrients in the coastal North Sea (transboundary nutrients). The three case studies provided the building blocks on which to develop a conceptual model to identify issues that are likely to influence the achievement of GEnS for the MSFD descriptors in the area. The DriverPressure-State-Welfare-Response (DPSWR) framework (Cooper 2013), which was derived from the original Driver-PressureState-Impact-Response (DPSIR) framework but with Impact replaced by (change in human) Welfare, was used as a methodology to structure the case studies investigated (Table 1), with 9 of the 11 MSFD GEnS descriptors believed to be affected by the activities described (D1-D7, D10, D11; Fig. 2).

A number of "hard" models and statistical methods were applied during each of the case studies. However, because our aim was to examine the wider social-ecological system, which can at best be described as messy and highly complex, a method was required that would allow us to take the case study expertise, use it in a new way, and gain a new perspective. For these reasons, the soft systems approach was chosen.

\section{Soft systems approach}

Soft systems methodology is a systematic approach for tackling real-world problematic situations (Checkland and Poulter 2006). It does this by treating the notion of "system" as a construct rather than a concrete entity. It is particularly useful in those situations in which there is a lack of agreement regarding what constitutes the problem, or indeed, hundreds of inter-related problems. In such situations, there may be a number of different perspectives, values, and beliefs regarding which aspects of the situation are most important and how to address them. In addition, changing just one aspect of the situation may have a knock-on effect on other aspects. The purpose of the soft systems approach is to develop a comprehensive understanding of the various aspects of the problematic situation and to enable the drawing of different boundaries around what the system is perceived to be. The models developed as part of this process are not supposed to represent the real world but rather to allow us to structure thinking about the real world.

Fig. 1. Map detailing the spatial location(s), within the Northeast Atlantic (NEA), of the three case studies used as the basis for this study.

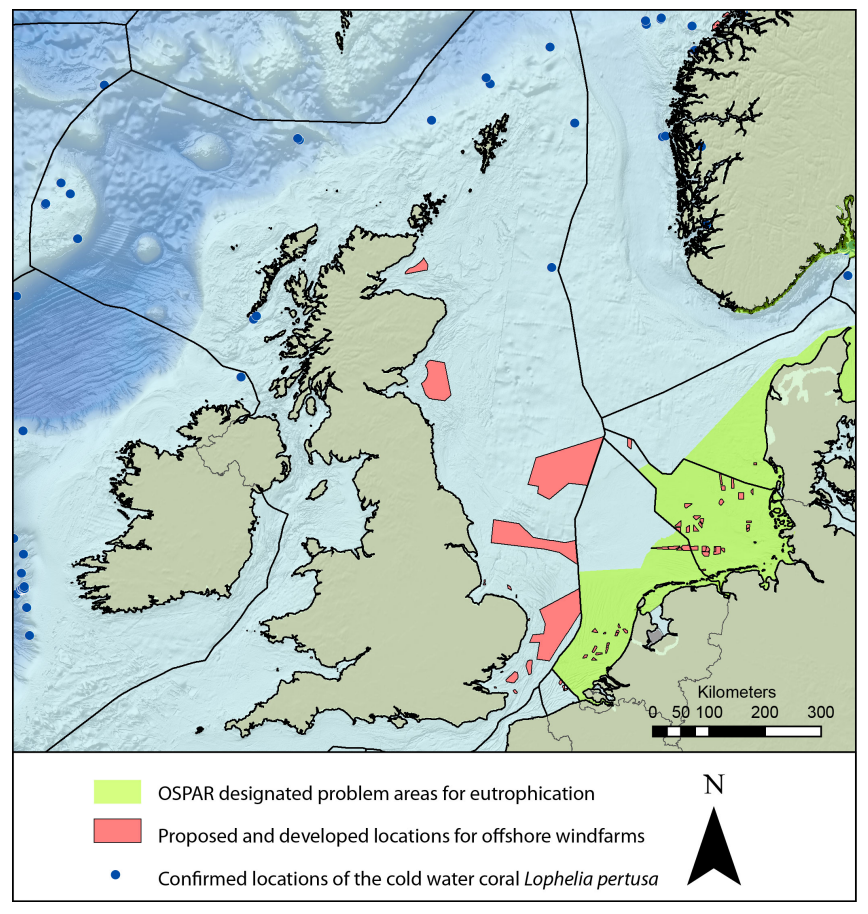

An expert workshop was held in November 2012 during an annual project meeting for the KnowSeas Project in Bruges, Belgium, in which the soft systems methodology was used to explore the complexities involved in achieving GEnS in the NEA. Seventeen participants were drawn from those who had worked on the NEA case studies during the KnowSeas project. In accordance with the method described by Checkland and Poulter (2006), and in the context of MSFD implementation in the NEA, participants worked collaboratively to undertake the following steps:

1. Describe the perceived real-world problematical situation based on experience gained during the case study research.

2. Create a purposeful conceptual model based on a combined worldview.

3. Use the model to question the real situation.

4. Define the actions required to improve the situation.

This allowed for a comprehensive examination of the widely varying spatial and temporal scales of Pressures, State changes, Welfare effects, and regulatory Response that need to be considered when trying to establish whether and how GEnS can be achieved.

\section{RESULTS}

The real-world problematic situation was discussed by workshop participants. They defined it as the difficulties in achieving GEnS in the NEA because of the complex arrangements of 
Table 1. Driver-Pressure-State-Welfare-Response (DPSWR) framework components of each of the three case studies used as the basis for this study.

\begin{tabular}{|c|c|c|c|c|c|}
\hline Drivers & Pressures & State & Welfare & Response & References \\
\hline $\begin{array}{l}\text { Offshore wind farms } \\
\text { Demand for energy; } \\
\text { security of supply; } \\
\text { commitments to } \\
\text { reduce carbon } \\
\text { emissions; focus on } \\
\text { renewable energy; } \\
\text { regional development }\end{array}$ & $\begin{array}{l}\text { Habitat disturbance; } \\
\text { smothering; } \\
\text { electromagnetic } \\
\text { change; noise; } \\
\text { collision potential; } \\
\text { vectors for invasive } \\
\text { species; increased food } \\
\text { supply after } \\
\text { construction }\end{array}$ & $\begin{array}{l}\text { Noise as example: } \\
\text { Marine mammals and } \\
\text { fish with swim } \\
\text { bladders change } \\
\text { behavior, are injured, } \\
\text { or die, affecting } \\
\text { distribution and } \\
\text { abundance of species }\end{array}$ & $\begin{array}{l}\text { Contributes to societal } \\
\text { goals such as } \\
\text { reduction of } \mathrm{CO}_{2} \\
\text { emissions and can } \\
\text { impact local and } \\
\text { regional development } \\
\text { of coasts; may reduce } \\
\text { area available to fish }\end{array}$ & $\begin{array}{l}\text { Measures can be } \\
\text { imposed or } \\
\text { encouraged to reduce } \\
\text { impact on State by } \\
\text { technical solutions, } \\
\text { spatial planning, or } \\
\text { timing of operations }\end{array}$ & $\begin{array}{l}\text { Gill } 2005 \\
\text { Breton and Moe } 2009 \\
\text { Tougaard et al. } 2009 \\
\text { Lange et al. } 2010 \\
\text { Lindeboom et al. } 2011 \\
\text { Alexander et al. } 2013 \\
\text { O'Higgins and Gilbert } \\
\text { 2014 }\end{array}$ \\
\hline $\begin{array}{l}\text { Lophelia reefs } \\
\text { Main reef-forming } \\
\text { species in Northeast } \\
\text { Atlantic; however } \\
\text { potential conflict with } \\
\text { deep-water fisheries }\end{array}$ & $\begin{array}{l}\text { Reefs and slow } \\
\text { growing and } \\
\text { susceptible to } \\
\text { destruction by bottom } \\
\text { trawls; ocean } \\
\text { acidification also a } \\
\text { risk }\end{array}$ & $\begin{array}{l}\text { In present state, } \\
\text { provide habitat for } \\
\text { many organisms as } \\
\text { well as feeding and } \\
\text { breeding grounds for } \\
\text { commercially } \\
\text { important fish species }\end{array}$ & $\begin{array}{l}\text { Existence and } \\
\text { educational values for } \\
\text { society }\end{array}$ & $\begin{array}{l}\text { Creation of no-fishing } \\
\text { zones; banning of } \\
\text { certain gear types; } \\
\text { achieving stabilization } \\
\text { of increasing ocean } \\
\text { acidification by } \\
\text { reaching targets for } \\
\text { GHG reductions }\end{array}$ & $\begin{array}{l}\text { Hall-Spencer et al. } 2002 \\
\text { Costello et al. } 2005 \\
\text { Hall-Spencer et al. } 2009 \\
\text { Foley et al. } 2010 \\
\text { Howell et al. } 2011 \\
\text { Söffker et al. } 2011 \\
\text { Purser et al. } 2013 \\
\text { Jackson et al. } 2014\end{array}$ \\
\hline $\begin{array}{l}\text { Transboundary nutrients } \\
\text { Application of } \\
\text { fertilizers, dependent } \\
\text { on market forces and } \\
\text { Common Agricultural } \\
\text { Policy; societal } \\
\text { demand for food, } \\
\text { cleaning products, and } \\
\text { sewage collection; } \\
\text { increased urbanization } \\
\text { and population } \\
\text { growth }\end{array}$ & $\begin{array}{l}\text { Increased nutrient } \\
\text { loading in rivers and } \\
\text { subsequently coastal } \\
\text { waters; treatments do } \\
\text { not entirely get rid of } \\
\text { excess nutrients }\end{array}$ & $\begin{array}{l}\text { Additional nutrients } \\
\text { may lead to increased } \\
\text { primary production, } \\
\text { affecting fish stocks } \\
\text { and seabirds; can also } \\
\text { lead to eutrophication } \\
\text { adversely affecting fish } \\
\text { and shellfish } \\
\text { populations; poor } \\
\text { water quality; toxic } \\
\text { phytoplankton species }\end{array}$ & As State & $\begin{array}{l}\text { Derived from land- } \\
\text { based human } \\
\text { activities; regulatory } \\
\text { measures must be } \\
\text { targeted appropriately }\end{array}$ & $\begin{array}{l}\text { Vermaat et al. } 2008 \\
\text { Van Beusekom et al. } \\
2009 \\
\text { Lenhart et al. } 2010 \\
\text { Ferreira et al. } 2011 \\
\text { Los et al. 2014 } \\
\text { Troost et al. } 2014\end{array}$ \\
\hline
\end{tabular}

socioeconomic demands and controls, benefit allocation mechanisms, policy fragmentation and differing spatial scales of management.

\section{Conceptual model}

To link the political, social, economic, and ecological elements of the NEA system, we developed a conceptual model based on the DPSWR framework (Cooper 2013). This model identified the complexity of social, economic, and ecological factors that influence a desired outcome in the context of the specific NEA case studies (Fig. 3).

The model in Figure 3 aims to show causal relationships among selected features of the social system within an EU member or associated state and the marine ecosystem that the state is responsible for. At the heart of the model are the relationships between ecosystem State and human Welfare. The ecosystem provides services that, distributed by markets or public provision, benefit welfare by satisfying human well-being needs. At the same time, the use of these services leads to Pressures on the marine ecosystem that may change its State, with consequent impact on services and Welfare. According to the DPSWR framework, this leads to a societal Response acting either on the societal Drivers of these Pressures or on the coupling between Drivers and Pressures. Following Elliott (2011), the relevant Pressures, i.e., those that are vulnerable to management by the member state, are called endogenous, in contrast to exogenous Pressures such as those caused by climate change, which can only be managed, if at all, by collective global action.

Societal Responses typically entail political and economic costs. In the absence of transnational agreements, Responses would differ between countries because each national governance system would be motivated by specific national considerations. A consequence might be the relocation to other member states or to states outside of the EU of externalities associated with use of marine ecosystem services. The MSFD is shown externally to the main elements of the modeled social-ecological system, providing guidance through the treaty obligations of the member state to the other states of the EU. These obligations include those of monitoring, reporting, and managing in relation to targets agreed with other states. However, according to the principle of subsidiarity, i.e., that social problems should be dealt with at the most immediate (or local) level consistent with their solution, each state implements the directive in its own way.

\section{Issues arising from model}

The development of the conceptual model and the associated discussion raised four issues that may complicate the implementation of the MSFD in the NEA region. The majority arose in the Pressures and State sections of the model. They are as follows: 
Fig. 2. Major maritime and land-based drivers, associated human activities that result in pressures on the marine environment, and the potential direct (uppercase) and indirect (lowercase) effects on the 11 Marine Strategy Framework Directive (MSFD) Good Environmental Status (GEnS) Descriptors related to 3 case studies from the Northeast Atlantic. D1 indicates Biodiversity; D2, Nonindigenous species; D3, Commercial fish and shellfish; D4, Food webs; D5, Eutrophication; D6, Seafloor integrity; D7, Hydrographical conditions; D8, Contaminants; D9, Contaminants in fish and shellfish; D10, Marine litter; D11, Underwater noise.

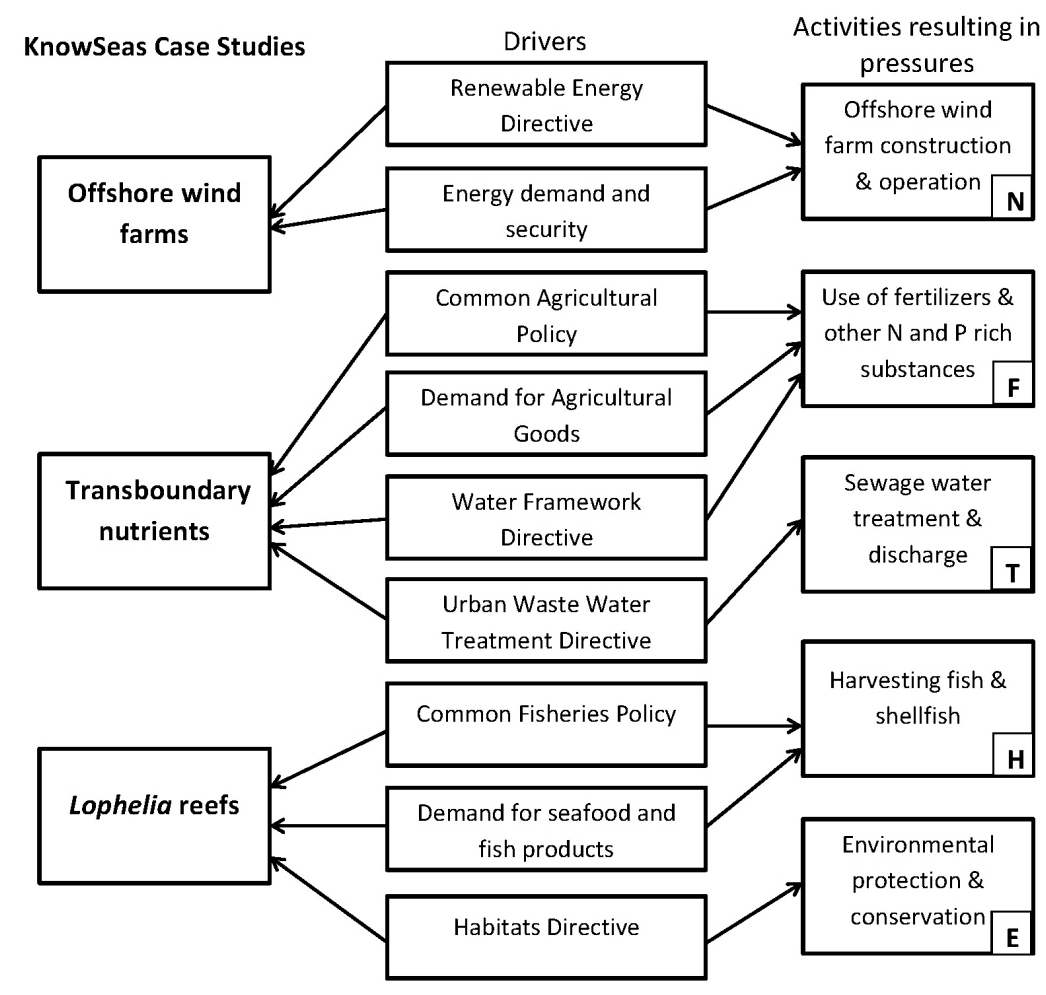

State: MSFD descriptors affected by activity

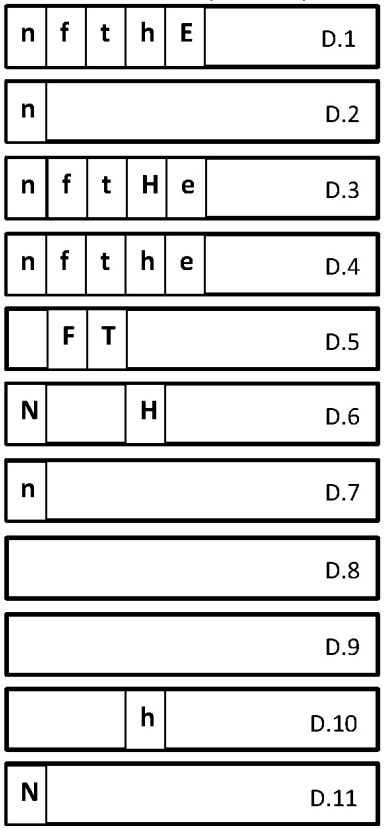

UPPER CASE letters indicate a direct impact; lower case letters indicated an indirect impact
1. Variability in the ecosystem. Although the DPSWR framework is primarily concerned with anthropogenic State change, in practice this may be difficult to disentangle from changes that would have occurred even in the absence of related Pressures. In this light, what is labeled as State is perhaps better seen as an attractor in ecosystem state space (Holling 1973). In any event, ecosystem indicators may change over time for reasons other than anthropogenic Pressures, and such variability has implications for setting targets. Within the model, natural system variability is represented within the Pressures box by "nonmanageable Drivers" and "exogenous (unmanageable) Pressures."

2. Cumulative effects. Changes in human society take time to implement, and in the meantime Pressures may increase despite regulation of Drivers because of legacy and future effects. Past behaviors may have generated a reservoir of Pressure either within or upstream of the marine ecosystem (O'Higgins et al. 2014), exemplified by phosphorus-rich terrestrial catchments or phosphorus-rich marine sediments (Puttonen et al. 2014). Quantifying cumulative effects and subsequent impacts presents a difficult management challenge (Van der Wal et al. 2006, Stelzenmüller et al. 2010, Crowe et al. 2012, O'Mahony et al. 2014) and is acknowledged as being a Europe-wide issue in relation to environmental management and assessment. Cumulative effects are represented in the model at the stage of PressureState coupling, through some combination of "endogenous (manageable) Pressures" with the potential for additional exogenous Pressures.

3. Ecosystem resilience. Resilience is the emergent ecosystem property that resists Pressures, adapts systems to pressure, or brings about recovery when pressure is relaxed (Folke et al. 2004). Tett et al. (2013) argued that GEnS could be equated with high resilience. Current ecological theory holds that damage to ecosystem organization (Mageau et al. 1995) reduces resilience, leading to regime shift, which is often conceptualized as a move to a new basin of attraction. A resilient ecosystem may show little response to increasing pressure; hence, conventional indicators may be of little help in detecting State change until too late. Scheffer et al. (2009) suggested that increasing variability might provide advance warning of regime shift. Resilience is represented in the State box and can affect Pressure-State coupling. 
Fig. 3. Conceptual model showing those elements of the DPSWR framework that have to be taken into account to achieve GEnS. The individual elements of the model are described in the text.

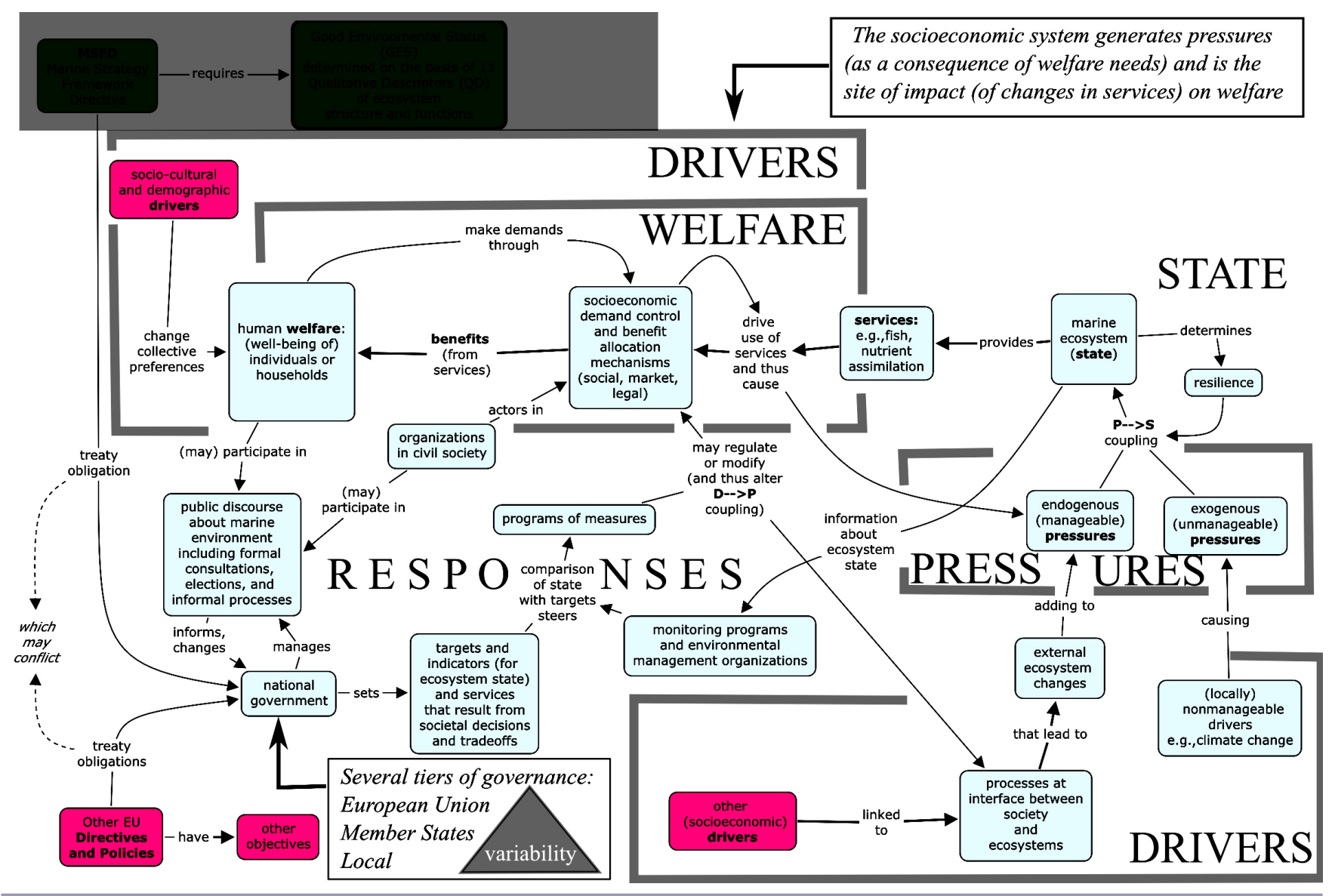

4. Conflicting policy targets. Many policies affect marine areas (Kannen 2014). Even specifically marine legal instruments such as the MSFD and the recently EU-adopted Directive on Maritime Spatial Planning are in their argumentation taking different perspectives. Similarly, the EU Blue Growth strategy, which aims to support sustainable growth in Europe's marine and maritime sectors, has potential to clash with the objective of the MSFD, which has the overall aim of promoting sustainable use. This indicates a clash of goals in society concerning human use of marine areas and explains why in many cases decisions include compromises between use and protection of ecosystem goods and services. The clash occurs at several levels of governance. Within member states it is described in the model by the boxes Public Discourse, Human Welfare, Socio-economic Demand, and Targets and Indicators for Ecosystem States and Services. At the EU level, it is described in terms of conflicts between member states' treaty obligations under the MSFD and under other EU directives.

\section{Conceptual model testing}

The four critical issues were then tested against the real-world case studies. The results indicated that the issue of policy conflict was prevalent throughout the case studies; however, not every issue identified by the conceptual model was present in every case study (Table 2).

Three of the critical issues were identified within the offshore wind farm case study. Cumulative effects may occur through Pressures; for example, some fish species may be subject to the combined effects of electromagnetic change and collision risk. Ecosystem resilience related to offshore wind farm installations is still an unknown. For that reason, the participants believed that it should be included as a critical issue in this case study. In terms of policy conflict, the Drivers of offshore renewable energy, e.g., demand for energy and security of supply, occur in tandem with a desire to reduce the environmental impact of human activities.

Two of the critical issues were identified within the Lophelia reefs case study. In the case of cumulative effects, Lophelia reefs may be subject to combined Pressures such as bottom trawling and ocean acidification. Conflicting policy was also recognized as a critical issue affecting Lophelia. Some countries have policies to ensure the continued existence of the fishing industry; however the MSFD aims to preserve biodiversity, the very thing that the fishing industry may prevent.

All four of the critical issues could be identified within the transboundary nutrients case study. Eutrophication-related 
Table 2. Critical issues found within each case study.

\begin{tabular}{lccc}
\hline \hline & Variability in ecosystem & Cumulative effects & Ecosystem resilience \\
\hline Offshore wind farms & $\bullet$ & $\bullet$ \\
Lophelia reefs & $\bullet$ & $\bullet$ & $\bullet$ \\
Transboundary nutrients & $\bullet$ & $\bullet$ & $\bullet$ \\
\hline
\end{tabular}

variability occurs on a range of spatial and temporal scales, and includes an underlying trend of increasing temperature that may also affect resilience. An obvious cumulative effect with respect to eutrophication is that multiple river loads and other nutrient inputs like atmospheric deposition will all contribute to the nutrient concentrations in the North Sea. Finally, although the MSFD aims to mitigate eutrophication by reducing nutrient concentrations, other legislation such as Natura 2000 (http://ec. europa.eu/environment/nature/natura2000/) aims to sustain or increase certain bird or fish populations. However, nutrient concentrations may lead to reduced productivity and hence to a decrease in the fish or bird populations that directly or indirectly depend on this productivity.

\section{DISCUSSION}

The key finding of this study was the four common critical issues found to complicate the implementation of the MSFD: variability in the ecosystem, cumulative effects, ecosystem resilience, and conflicting policy, although these were not found to occur across all case studies. However, understanding these issues more clearly may lead to progress in addressing continued ecosystem deterioration. It should be remembered that this study was based on a conceptual model, and models present necessarily strong abstractions of reality. Soft systems methodology and the creation of conceptual models through this process are only a "process of inquiry" into problematical situations (Checkland and Poulter 2006). Also, the key method of this study was an expert workshop, and limitations to expert knowledge always exist.

\section{Variability in the ecosystem}

All natural systems exhibit some degree of variability in space and time, which can impose challenges in setting realistic GEnS targets (Kenny et al. 2009, Blenckner et al. 2015). If the overall aim is to achieve sustainable exploitation of ecosystem goods and services, natural variations in the ecosystem must be taken into account. Variability occurs on a range of spatial and temporal scales. These include an underlying trend of increasing temperature caused by global warming, which has had a dominant influence on biological systems in the NEA since the mid-19th century (Edwards et al. 2013). This is overlain by basinwide alternate warming and cooling periods, with a frequency of about 60 years, described as the Atlantic Multidecadal Oscillation. Even small changes in temperature can have significant effects on the onset of the spring phytoplankton bloom, the relative abundance of zooplankton, and the abundance and distribution of commercial fish species (Edwards et al. 2013, Nye et al. 2014). Hence, these changes influence descriptors for biodiversity (D1), nonindigenous species (D2), commercial fish and shellfish (D3), food webs (D4), eutrophication (D5), and seafloor integrity (D6). In addition, warmer waters can allow the spread of harmful bacteria and viruses (e.g., Vibrio sp., Reilly et al. 2013) and lead to increased outbreaks of toxic algal blooms (D9 contaminants in fish and shellfish). Fluctuations in precipitation can lead to significant variability in nutrient loadings and hence influence eutrophication status (de Vries et al. 1998).

Natural ecosystem variability is not something that can be readily dealt with through changes to decision making, management systems, or governance. However, it is an issue that should certainly be borne in mind during these processes.

\section{Cumulative effects}

Repeated Pressures from one or more maritime or land-based activity may produce a cumulative effect on ecosystem State. Although cumulative effects may be conceptualized readily, establishing causal relationships and estimating the magnitude of the effects are much more problematic (ICES 2013), and there is limited guidance for decision makers on how to minimize them (Cooper 2004).

Cumulative effects may occur in a number of ways. Spatial overlap may mean that the "footprint" of one Pressure overlaps with that of adjacent similar Pressures, e.g., construction of multiple wind turbines, to which there may be a nonlinear response or tipping point on the distribution or breeding success of seabirds at increasing spatial extents (Busch et al. 2013). Multiple sources may lead to cumulative effects, such as a Pressure from multiple Drivers that acts on one or more features, e.g., multiple river inputs of nutrients to the coastal zone that results in eutrophication. Finally, additive/synergistic effects may be found when two or more Pressures affect a feature: e.g., ocean acidification and fishing pressures on Lophelia reefs (Tittensor et al. 2010).

Currently, sector-based legislation allows the introduction of controls to modify the effects of particular activities. Unfortunately, it may require apportioning the effect of each sector/activity on an environmental State descriptor, as well as recognizing that some of these will be land based, e.g., agricultural production as a source of nutrients under the influence of the EU Common Agriculture Policy and effects on D5. Some GEnS descriptors may have multiple and poorly defined Drivers and Pressures, such as the effects of land-based waste management, coastal tourism, and shipping on marine litter (D10).

\section{Ecosystem resilience}

In many cases, major problems exist concerning the assessment of the effects of human activities on the resilience of marine systems. A particular example is offshore wind farms, which are a recently developed, and still developing, sector in which longterm time series of monitoring data do not exist and for which there is a high level of uncertainty in assessing impacts on ecosystem structures and processes. In some cases, e.g., eutrophication, the different components of the North Sea 
ecosystem show different responses in terms of resilience. Timing of phytoplankton blooms in the eutrophic coastal areas is resilient (Wiltshire et al. 2008), but climate factors like winter temperature play a dominant role (e.g., van Beusekom et al. 2009). Also, the decrease in summer phytoplankton biomass in response to decreasing nitrogen loads supports the resilience of the phytoplankton community to nutrient disturbances. In any case, it should be noted that modern coastal ecosystems, including those of the North Sea, are strongly degraded compared with earlier system States deduced from palaeontological, archaeological, historical, and ecological records (Lotze et al. 2005, 2006).

Adaptive management recognizes that the natural resources being relied on by society will always change; therefore, humans must be flexible in responding to these new situations. This is likely to be a key way to deal with continuously changing environments resulting from changes to ecological resilience caused by human activity. The precautionary principle, i.e., if an action or policy has a suspected risk of causing harm to the public or the environment in the absence of scientific consensus that the action or policy is not harmful, means that the burden of proof that it is not harmful falls on those taking an action. Precaution and adaptive management have been advanced in response to the recognition that scientific uncertainty and limited understanding are often significant features of decision making, particularly in relation to environmental management. However, these principles are intimately connected with values that may vary from one decision maker to another, meaning that it is important that there be increased specificity in exercising these principles. For example, what kind of follow-up measures will be used to monitor what kinds of remaining uncertainties (Benedickson et al. 2005)?

\section{Conflicting policy}

The three case studies, all of which relate to human activities within or nearby the marine environment, provide clear examples of policy conflict. Countries within the NEA area subscribe to the European agenda of Blue Growth, the long-term strategy to support sustainable growth in the marine and maritime sectors, including those such as aquaculture, marine tourism, fishing, marine biotechnology, seabed mining, and ocean energy. However, in the case of the MSFD, there are requirements that biological diversity is maintained (D1) and that the quality and occurrence of habitats, of which cold-water corals are an example, and the distribution of species are in line with prevailing physiographic, geographic, and climatic conditions. It is also required that populations of commercially exploited fish and shellfish are healthy (D3), and cold-water corals contribute toward achieving this criterion by providing, e.g., nursery areas. Attempts to conserve species by closing areas to fishing or hydrocarbon exploration or development may mean that other maritime industries are unable to operate in some ocean areas. Alternatively, enabling maritime growth without conservation of these species may be to their detriment. In many cases, the response is to minimize detrimental effects as development proceeds. This may be adequate to comply with the MSFD at this relatively early stage of implementation but might present challenges in the future, particularly when cumulative effects become more apparent and issues relating to ecosystem resilience are better understood.
Policy conflicts between economic and policy sectors must be solved by setting and agreeing on political priorities. Although institutions and governance processes develop at the national level, a major challenge is the need for transnational cooperation mechanisms, not only in specific sectors such as energy or fishing, but also in terms of marine spatial planning and marine environmental management as a whole. This needs to go beyond directives at the EU level and reflect the specific needs in the different European marine regions, involve Regional Sea conventions, and could provide key mechanisms of collaboration and information exchange as well as a vision of how to deal with transnational components (Kannen 2014). A first example of how such a vision could look is the BaltSeaPlan Vision for Marine Spatial Planning in the Baltic 2030 (Gee 2013).

\section{CONCLUSIONS}

The achievement of GEnS targets for the marine environment requires the recognition and negotiation of trade-offs across a broad policy landscape involving a wide variety of stakeholders in the public and private sectors. These include policies specifically aimed at managing maritime activities, those targeted at landbased activities, and overarching policies relating, for example, to energy security, conservation, food security, and meeting international targets for a reduction in $\mathrm{CO}_{2}$ emissions. Policy conflicts are inevitable, so it is essential that mechanisms are provided to facilitate dialogue to discuss priorities, explore management and policy, and encourage informed decision making.

Targets for GEnS need to be viewed within the context of the sustainable utilization of ecosystem services and the ecosystem approach to management. The potential cumulative effects of several Pressures may introduce significant uncertainty, particularly in selecting appropriate management measures. In addition, there are endogenous Pressures that society cannot control and variability within the system, e.g., climate change, that cannot be controlled on a timescale of decades. Such Pressures may affect several of the MSFD descriptors and need to be recognized to ensure that GEnS targets are achievable. Also, questions relating to the resilience of the affected ecosystem to specific Pressures must be raised, despite a lack of current knowledge.

Management of the North Sea has been the subject of scientific enquiry for decades, as have other regional sea areas. The four critical issues identified during this study are likely to also be applicable to the implementation of MSFD in other regional seas, and indeed should be considered in marine environmental management beyond Europe. Achieving good management and reaching GEnS require multidisciplinary assessments. The soft systems approach provides one mechanism for bringing multidisciplinary information together to look at the problems in a different light. We have tested the application of the soft systems approach in the context of implementing MSFD and achieving GEnS, primarily using members of the scientific community. Future work should iterate the process while including the policy community and other actors in the process, using their input to enrich the model exercise and arrive at workable pathways to support implementation. 
Responses to this article can be read online at: http://www.ecologyandsociety.org/issues/responses. $\mathrm{php} / 7394$

\section{Acknowledgments:}

This work was performed under the EU 7th Framework project Knowseas (Knowledge-based sustainable management of Europe's Seas). Peter Kershaw was partially supported by the Department for Environment, Food and Rural Affairs

\section{LITERATURE CITED}

Alexander, K. A., T. Potts, and T. A. Wilding. 2013. Marine renewable energy and Scottish west coast fishers: exploring impacts, opportunities and potential mitigation. Ocean \& Coastal Management 75:1-10. http://dx.doi.org/10.1016/j.ocecoaman.2013.01.005

Benedickson, J., N. Chalifour, Y. Prévost, J. A. Chandler, A. Dabrowski, S. Findlay, A. Déziel, H. C. McLeod-Kilmurray, and D. Lane. 2005. Practicing precaution and adaptive management: legal, institutional and procedural dimensions of scientific uncertainty. Final report to the SSHRC \& Law Commission of Canada. University of Ottawa, Ottawa, Ontario, Canada. [online] URL: http://www.uottawa.ca/ie/English/Reports/JBPP_Final_Report. pdf

Bertram, C., and K. Rehdanz. 2013. On the environmental effectiveness of the EU Marine Strategy Framework Directive. Marine Policy 38:25-40. http://dx.doi.org/10.1016/j.marpol.2012.05.016

Blenckner, T., A. Kannen, A. Barausse, C. Fischer, J. Heymans, T. Luisetti, V. Todorova, M. Valman, and L. Mee. 2015. Past and future challenges in managing European seas. Ecology and Society 20(1): 40. http://www.ecologyandsociety.org/vol20/iss 1/art40/

Breton, S.-P., and G. Moe. 2009. Status, plans and technologies for offshore wind turbines in Europe and North America. Renewable Energy 34:646-654. http://dx.doi.org/10.1016/j. $\underline{\text { renene. } 2008.05 .040}$

Busch, M., A. Kannen, S. Garthe, and M. Jessopp. 2013. Consequences of a cumulative perspective on marine environmental impacts: offshore wind farming and seabirds at North Sea scale in context of the EU Marine Strategy Framework Directive. Ocean \& Coastal Management 71:213-224. http://dx. doi.org/10.1016/j.ocecoaman.2012.10.016

Checkland, P., and J. Poulter. 2006. Learning for action: a short definitive account of soft systems methodology and its use for practitioners, teachers and students. Wiley, Chichester, UK.

Cole, M., P. Lindeque, C. Halsband, and T. S. Galloway. 2011. Microplastics as contaminants in the marine environment: a review. Marine Pollution Bulletin 62:2588-2597. http://dx.doi. org/10.1016/j.marpolbul.2011.09.025

Cooper, L. M. 2004. Guidelines for cumulative effects assessment in SEA of plans. EPMG occasional paper 04/LMC/CEA. Imperial College London, London, UK.

Cooper, P. 2013. Socio-ecological accounting: DPSWR, a modified DPSIR framework, and its application to marine ecosystems. Ecological Economics 94:106-115. http://dx.doi. org/10.1016/j.ecolecon.2013.07.010

Costello, M. J., M. McCrea, A. Freiwald, T. Lundälv, L. Jonsson, B. J. Bett, T. C. E. van Weering, H. de Haas, J. M. Roberts, and D. Allen. 2005. Role of cold-water Lophelia pertusa coral reefs as fish habitat in the NE Atlantic. Pages 771-805 in A. Freiwald and J. M. Roberts, editors. Cold-water corals and ecosystems. Springer, Berlin and Heidelberg, Germany. http://dx.doi.org/10.1007/3-54$\underline{0-27673-4 \quad 41}$

Crowe, T. P., J. E. Fitch, C. L. J. Frid, and P. J. Somerfield. 2012. Strategic review of sectoral impacts on coastal marine ecosystems in Ireland. Report prepared as part of the EPA funded SIMBIOSYS project examining sectoral influences on biodiversity and ecosystem services. Environmental Protection Agency, Wexford, Ireland.

de Vries, I., R. N. M. Duin, J. C. H. Peeters, F. J. Los, M. Bokhorst, and R. W. P. M. Laane. 1998. Patterns and trends in nutrients and phytoplankton in Dutch coastal waters: comparison of timeseries analysis, ecological model simulation, and mesocosm experiments. ICES Journal of Marine Science 55:620-634. http:// dx.doi.org/10.1006/jmsc.1998.0399

Edwards, M., G. Beaugrand, P. Helaouët, J. Alheit, and S. Coombs. 2013. Marine ecosystem response to the Atlantic Multidecadal Oscillation. PLoS ONE 8(2):e57212. http://dx.doi. org/10.1371/journal.pone.0057212

Elliott, M. 2011. Marine science and management means tackling exogenic unmanaged pressures and endogenic managed pressures — a numbered guide. Marine Pollution Bulletin 62:651-655. http:// dx.doi.org/10.1016/j.marpolbul.2010.11.033

European Parliament and the Council of the European Union. 2008. Directive 2008/56/EC of the European Parliament and of the Council of 17 June 2008 establishing a framework for community action in the field of marine environmental policy (Marine Strategy Framework Directive) OJ L164/19. Official Journal of the European Union 51:19-40.

Ferreira, J. G., J. H. Andersen, A. Borja, S. B. Bricker, J. Camp, M. Cardoso da Silva, E. Garcés, A.-S. Heiskanen, C. Humborg, L. Ignatiades, C. Lancelot, A. Menesguen, P. Tett, N. Hoepffner, and U. Claussen. 2011. Overview of eutrophication indicators to assess environmental status within the European Marine Strategy Framework Directive. Estuarine, Coastal and Shelf Science 93:117-131. http://dx.doi.org/10.1016/j.ecss.2011.03.014

Foley, N. S., T. M. van Rensburg, and C. W. Armstrong. 2010. The ecological and economic value of cold-water coral ecosystems. Ocean \& Coastal Management 53:313-326. http://dx. doi.org/10.1016/j.ocecoaman.2010.04.009

Folke, C., S. Carpenter, B. Walker, M. Scheffer, T. Elmqvist, L. Gunderson, and C. S. Holling. 2004. Regime shifts, resilience, and biodiversity in ecosystem management. Annual Review of Ecology, Evolution, and Systematics 35:557-581. http://dx.doi. org/10.1146/annurev.ecolsys.35.021103.105711

Gee, K. 2013. Trade-offs between seascape and offshore wind farming values: an analysis of local opinions based on a cognitive belief framework. Dissertation. University of Göettingen, Göettingen, Germany. 
Gill, A. B. 2005. Offshore renewable energy: ecological implications of generating electricity in the coastal zone. Journal of Applied Ecology 42:605-615. http://dx.doi.org/10.1111/ j.1365-2664.2005.01060.x

Gulland, J. A. 1958. The conservation of fish stocks. Proceedings of the Nutrition Society 17:132-136. http://dx.doi.org/10.1079/ PNS19580027

Hall-Spencer, J., V. Allain, and J. H. Fosså. 2002. Trawling damage to Northeast Atlantic ancient coral reefs. Proceedings of the Royal Society of London B: Biological Sciences 269:507-511. http://dx. doi.org/10.1098/rspb.2001.1910

Hall-Spencer, J. M., M. Tasker, M. Soffker, S. Christiansen, S. Rogers, M. Campbell, and K. Hoydal. 2009. Design of Marine Protected Areas on high seas and territorial waters of Rockall Bank. Marine Ecology Progress Series 397:305-308. http://dx.doi. org/10.3354/meps08235

Holling, C. S. 1973. Resilience and stability of ecological systems. Annual Review of Ecology and Systematics 4:1-23. http://dx.doi. org/10.1146/annurev.es.04.110173.000245

Howell, K. L., R. Holt, I. S. P. Endrino, and H. Stewart. 2011. When the species is also a habitat: comparing the predictively modelled distributions of Lophelia pertusa and the reef habitat it forms. Biological Conservation 144:2656-2665. http://dx.doi. org/10.1016/j.biocon.2011.07.025

International Council for the Exploration of the Sea (ICES). 2013. Report of the Working Group for Marine Planning and Coastal Zone Management (WGMPCZM), 8-12 April. ICES Headquarters, Copenhagen, Denmark.

Jackson, E. L., A. J. Davies, K. L. Howell, P. J. Kershaw, and J. M. Hall-Spencer. 2014. Future-proofing marine protected area networks for cold water coral reefs. ICES Journal of Marine Science 71:2621-2629. http://dx.doi.org/10.1093/icesjms/fsu099

Kannen, A. 2014. Challenges for marine spatial planning in the context of multiple sea uses, policy arenas and actors based on experiences from the German North Sea. Regional Environmental Change 14:2139-2150. http://dx.doi.org/10.1007/s10113-012-0349-7

Kenny, A. J., H. R. Skjoldal, G. H. Engelhard, P. J. Kershaw, and J. B. Reid. 2009. An integrated approach for assessing the relative significance of human pressures and environmental forcing on the status of Large Marine Ecosystems. Progress in Oceanography 81:132-148. http://dx.doi.org/10.1016/j.pocean.2009.04.007

Kerckhof, F., R. J. Vink, D. C. Nieweg, and J. N. J. Post. 2006. The veined whelk Rapana venosa has reached the North Sea. Aquatic Invasions 1:35-37. [online] URL: http://www. aquaticinvasions.net/2006/AI_2006_1_1_Kerckhof_etal.pdf

Lange, M., B. Burkhard, S. Garthe, K. Gee, H. Lenhart, A. Kannen, and W. Windhorst. 2010. Analysing coastal and marine changes - offshore wind farming as a case study: Zukunft KuesteCoastal Futures Synthesis Report. Land-Ocean Interactions in the Coastal Zone Project (LOICZ) Reports and Studies No. 36. LOICZ International Project Office, Institute for Coastal Research, Geesthacht, Germany.

Lenhart, H.-J., D. K. Mills, H. Baretta-Bekker, S. M. van Leeuwen, J. van der Molen, J. W. Baretta, M. Blaas, X. Desmit,
W. Kühn, G. Lacroix, H. J. Los, A. Ménesguen, R. Neves, R. Proctor, P. Ruardij, M. D. Skogen, A. Vanhoutte-Brunier, M. T. Villars, and S. L. Wakelin. 2010. Predicting the consequences of nutrient reduction on the eutrophication status of the North Sea. Journal of Marine System 81:148-170. http://dx.doi.org/10.1016/ j.jmarsys.2009.12.014

Lindeboom, H. J., H. J. Kouwenhoven, M. J. N. Bergman, S. Bouma, S. Brasseur, R. Daan, R. C. Fijn, D. de Haan, S. Dirksen, R. van Hal, R. H. R. Lambers, R. ter Hofstede, K. L. Krijgsveld, M. Leopold, and M. Scheidat. 2011. Short-term ecological effects of an offshore wind farm in the Dutch coastal zone; a compilation. Environmental Research Letters 6:035101. http://dx.doi. org/10.1088/1748-9326/6/3/035101

Los, F. J., T. A. Troost, and J. K. L. Van Beek. 2014. Finding the optimal reduction to meet all targets-applying Linear Programming with a nutrient tracer model of the North Sea. Journal of Marine System 131:91-101. http://dx.doi.org/10.1016/ j.jmarsys.2013.12.001

Lotze, H. K., H. S. Lenihan, B. J. Bourque, R. H. Bradbury, R. G. Cooke, M. C. Kay, S. M. Kidwell, M. X. Kirby, C. H. Peterson, and J. B. C. Jackson. 2006. Depletion, degradation, and recovery potential of estuaries and coastal seas. Science 312:1806-1809. http://dx.doi.org/10.1126/science.1128035

Lotze, H. K., K. Reise, B. Worm, J. van Beusekom, M. Busch, A. Ehlers, D. Heinrich, R. C. Hoffmann, P. Holm, C. Jensen, O. S. Knottnerus, N. Langhanki, W. Prummel, M. Vollmer, and W. J. Wolff. 2005. Human transformations of the Wadden Sea ecosystem through time: a synthesis. Helgoland Marine Research 59:84-95. http://dx.doi.org/10.1007/s10152-004-0209-z

Mageau, M. T., T. R. Constanza, and R. E. Ulanowicz. 1995. The development and initial testing of a quantitative assessment of ecosystem health. Ecosystem Health 1:201-213.

Mee, L., P. Cooper, A. Kannen, A. J. Gilbert, and T. O’Higgins. 2015. Sustaining Europe's seas as coupled social-ecological systems. Ecology and Society 20(1): 1. http://dx.doi.org/10.5751/ ES-07143-200101

Mendelssohn, I. A., G. L. Andersen, D. M. Baltz, R. H. Caffey, K. R. Carman, J. W. Fleeger, S. B. Joye, Q. Lin, E. Maltby, E. B. Overton, and L. P. Rozas. 2012. Oil impacts on coastal wetlands: implications for the Mississippi River Delta Ecosystem after the Deepwater Horizon oil spill. BioScience 62:562-574. http://dx.doi. org/10.1525/bio.2012.62.6.7

Millenium Ecosystem Assessment. 2005. Ecosystems and human well-being: current state and trends. Island Press, Washington, D. C., USA.

Myers, R. A., J. A. Hutchings, and N. J. Barrowman. 1996. Hypotheses for the decline of cod in the North Atlantic. Marine Ecology Progress Series 138:293-308. http://dx.doi.org/10.3354/ $\underline{\text { meps } 138293}$

Nye, J. A., M. R. Baker, R. Bell, A. Kenny, K. H. Kilbourne, K. D. Friedland, E. Martino, M. M. Stachura, K. S. Van Houtan, and R. Wood. 2014. Ecosystem effects of the Atlantic Multidecadal Oscillation. Journal of Marine Systems 133:103-116. http://dx.doi.org/10.1016/j.jmarsys.2013.02.006 
O'Higgins, T., P. Cooper, E. Roth, A. Newton, A. Farmer, I. C. Goulding, and P. Tett. 2014. Temporal constraints on ecosystem management: definitions and examples from Europe's regional seas. Ecology and Society 19(4): 46. http://dx.doi.org/10.5751/ ES-06507-190446

O’Higgins, T. G., and A. J. Gilbert. 2014. Embedding ecosystem services into the Marine Strategy Framework Directive: illustrated by eutrophication in the North Sea. Estuarine, Coastal and Shelf Science 140:146-152. http://dx.doi.org/10.1016/j. ecss.2013.10.005

O’Mahony, C., K. Kopke, S. Twomey, A. M. O’Hagan, E. Farrell, and J. Gault. 2014. Integrated coastal zone management in Ireland -meeting Water Framework Directive and Marine Strategy Framework Directive targets for Ireland's transitional and coastal waters through implementation of Integrated Coastal Zone Management. Report prepared under contract for Sustainable Water Network (SWAN). SWAN, Dublin, Ireland.

Ounanian, K., A. Delaney, J. Raakjær, and P. Ramirez-Monsalve. 2012. On unequal footing: stakeholder perspectives on the marine strategy framework directive as a mechanism of the ecosystembased approach to marine management. Marine Policy 36:658-666. http://dx.doi.org/10.1016/j.marpol.2011.10.008

Purser, A., C. Orejas, A. Gori, R. Tong, V. Unnithan, and L. Thomsen. 2013. Local variation in the distribution of benthic megafauna species associated with cold-water coral reefs on the Norwegian margin. Continental Shelf Research 54:37-51. http:// dx.doi.org/10.1016/j.csr.2012.12.013

Puttonen, I., J. Mattila, P. Jonsson, O. M. Karlsson, T. Kohonen, A. Kotilainen, K. Lukkari, J. M. Malmaeus, and E. Rydin. 2014. Distribution and estimated release of sediment phosphorus in the northern Baltic Sea archipelagos. Estuarine, Coastal and Shelf Science 145:9-21. http://dx.doi.org/10.1016/j.ecss.2014.04.010

Reilly, G., C. Reilly, E. Smith, and C. Baker-Austin. 2011. Vibrio alginolyticus-associated wound infection acquired in British waters, Guernsey, July 2011. Eurosurveillance 16:10.

Scheffer, M., J. Bascompte, W. A. Brock, V. Brovkin, S. R. Carpenter, V. Dakos, H. Held, E. H. van Nes, M. Rietkerk, and G. Sugihara. 2009. Early-warning signals for critical transitions. Nature 461:53-59. http://dx.doi.org/10.1038/nature08227

Söffker, M., K. A. Sloman, and J. M. Hall-Spencer. 2011. In situ observations of fish associated with coral reefs off Ireland. Deep Sea Research Part I: Oceanographic Research Papers 58:818-825. http://dx.doi.org/10.1016/j.dsr.2011.06.002

Stelzenmüller, V., J. Lee, A. South, and S. I. Rogers. 2010. Quantifying cumulative impacts of human pressures on the marine environment: a geospatial modelling framework. Marine Ecology Progress Series 398:19-32. http://dx.doi.org/10.3354/ $\underline{\text { meps08345 }}$

Tett, P., R. J. Gowen, S. J. Painting, M. Elliott, R. Forster, D. K. Mills, E. Bresnan, E. Capuzzo, T. F. Fernandes, J. Foden, R. J. Geider, L. C. Gilpin, M. Huxham, A. L. McQuatters-Gollop, S. J. Malcolm, S. Saux-Picart, T. Platt, M.-F. Racault, S. Sathyendranath, J. van der Molen, and M. Wilkinson. 2013.
Framework for understanding marine ecosystem health. Marine Ecology Progress Series 494:1-27. http://dx.doi.org/10.3354/ meps 10539

Thrush, S. F., and P. K. Dayton. 2002. Disturbance to marine benthic habitats by trawling and dredging: implications for marine biodiversity. Annual Review of Ecology and Systematics 33:449-473. http://dx.doi.org/10.1146/annurev.ecolsys.33.010802.150515

Tittensor, D. P., A. R. Baco, J. M. Hall-Spencer, J. C. Orr, and A. D. Rogers. 2010. Seamounts as refugia from ocean acidification for cold-water stony corals. Marine Ecology 31:212-225. http:// dx.doi.org/10.1111/j.1439-0485.2010.00393.x

Tougaard, J., J. Carstensen, J. Teilmann, H. Skov, and P. Rasmussen. 2009. Pile driving zone of responsiveness extends beyond $20 \mathrm{~km}$ for harbor porpoises (Phocoena phocoena (L.)). Journal of the Acoustical Society of America 126:11-14. http://dx. doi.org/10.1121/1.3132523

Troost, T. A., A. de Kluijver, and F. J. Los. 2014. Evaluation of eutrophication variables and thresholds in the Dutch North Sea in a historical context - a model analysis. Journal of Marine Systems 134:45-56. http://dx.doi.org/10.1016/j.jmarsys.2014.01.015

van Beusekom, J. E. E., M. Loebl, and P. Martens. 2009. Distant riverine nutrient supply and local temperature drive the long-term phytoplankton development in a temperate coastal basin. Journal of Sea Research 61:26-33. http://dx.doi.org/10.1016/j.seares.2008.06.005

Van der Wal, J. T., V. G. Blankendaal, H. P. van Dokkum, H. van der Brugh, J. A. van Dalfsen, and R. van Beek. 2006. Integration project application cumulative effects; Cumuleo 1.0 development. We@Sea project 2005-004. TNO Report 2006-DH-0199/C. We@Sea, Petten, Netherlands.

van Leeuwen, J., L. van Hoof, and J. van Tatenhove. 2012. Institutional ambiguity in implementing the European Union Marine Strategy Framework Directive. Marine Policy 36:636-643. http://dx.doi.org/10.1016/j.marpol.2011.10.007

Vermaat, J. E., A. McQuatters-Gollop, M. A. Eleveld, and A. J. Gilbert. 2008. Past, present and future nutrient loads of the North Sea: causes and consequences. Estuarine, Coastal and Shelf Science 80:53-59. http://dx.doi.org/10.1016/j.ecss.2008.07.005

Wiltshire, K. H., A. M. Malzahn, K. Wirtz, W. Greve, S. Janisch, P. Magelsdorf, B. F. J. Manly, and M. Boersma. 2008. Resilience of North Sea phytoplankton spring bloom dynamics: an analysis of long-term data at Helgoland Roads. Limnology and Oceanography 53:1294-1302. http://dx.doi.org/10.4319/10.2008.53.4.1294 